\title{
Data report: particle size analysis of sediments in the Nankai Trough, IODP Expedition 319 Hole C0009A ${ }^{1}$
}

\author{
Peter B. Flemings, ${ }^{2}$ Julia S. Reece, ${ }^{2,}{ }^{4}$ Julie Ditkof, ${ }^{2}$ Carmen C. Atkins, ${ }^{2}$ and Derek Sawyer ${ }^{3}$
}

\section{Chapter contents}

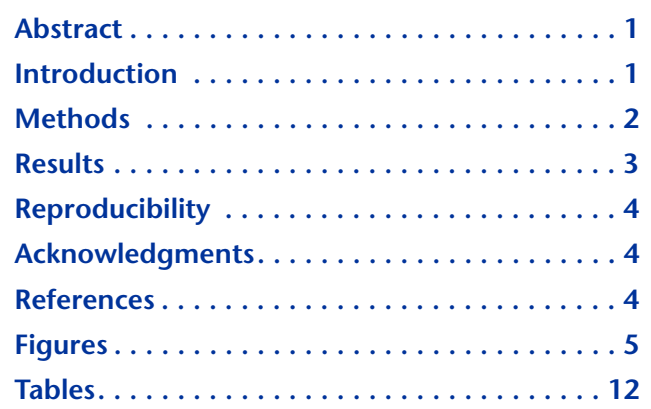

'Flemings, P.B., Reece, J.S., Ditkof, J., Atkins, C.C., and Sawyer, D., 2015. Data report: particle size analysis of sediments in the Nankai Trough, IODP Expedition 319 Hole C0009A. In Saffer, D., McNeill, L., Byrne, T., Araki, E., Toczko, S., Eguchi, N., Takahashi, K., and the Expedition 319 Scientists, Proc. IODP, 319: Tokyo (Integrated Ocean Drilling Program Management International, Inc.).

doi:10.2204/iodp.proc.319.203.2015

${ }^{2}$ Jackson School of Geosciences, University of Texas, Austin TX 78705, USA. Correspondence author: pflemings@jsg.utexas.edu

${ }^{3}$ Department of Earth and Environmental Sciences, University of Kentucky, Lexington KY 40506, USA. ${ }^{4}$ Department of Geophysics, Stanford University, Stanford CA 94305, USA.

\begin{abstract}
We analyzed the particle size distribution of 46 samples from Integrated Ocean Drilling Program (IODP) Expedition 319 Hole C0009A in the Kumano Basin of the Nankai Trough. Using Shepard's classification, we found that most samples fall into the clayey-silt classification. Clayey-silt is composed of 35\%-88\% siltsize particles, $11 \%-38 \%$ clay-size particles, and $<20 \%$ sand-sized particles by weight. However, six samples contain more sandsized particles and thus fall into either the sandy-silt or silty-sand category according to Shepard's classification. Samples at Site C0009 were analyzed over a depth range of 1529-1591 meters below seafloor using the wet-sieve and hydrometer methods.
\end{abstract}

\section{Introduction}

The Nankai Trough Seismogenic Zone Experiment (NanTroSEIZE) is a coordinated, multiexpedition drilling project designed to investigate fault slip behavior and the mechanics of seismogenesis along a subduction megathrust fault system through direct sampling, in situ measurements, and long-term monitoring associated with laboratory and numerical modeling studies (Saffer et al., 2009). As part of the NanTroSEIZE program, operations during Integrated Ocean Drilling Program (IODP) Expedition 319 included riser and riserless drilling, analyses of cuttings and core samples, downhole measurements and logging, observatory operations, and casing. Two sites were drilled during Expedition 319: Site C0009 in the Kumano forearc basin and Site C0010 across a major splay fault (termed the "megasplay") that bounds the seaward edge of the forearc basin near its updip terminus. We analyze the grain size of samples from Site C0009, which is located at the northern edge of the 3-D seismic volume acquired in 2006 (Fig. F1).

Hole C0009A was cored from 1509.7-1593.9 meters below seafloor (mbsf). The strata in this interval are late Miocene in age and are described as brown-gray silty-claystone, with minor interbeds of brown-gray siltstone-sandstone, and minor interbeds of light gray fine vitric tuff. Four lithofacies were defined based on the relative abundance of these lithologies (see the "Site C0009" chapter [Expedition 319 Scientists, 2010]).

To create a depth profile of particle sizes at Site C0009, we analyzed the particle size distribution of 46 samples. The results may 
provide a useful constraint to understand how lithology impacts physical properties (e.g., permeability, compressibility, and porosity) and may assist in interpreting the paleogeographic evolution of the $\mathrm{Ku}$ mano Basin. Our procedure and results are presented below (Tables T1, T2). A nomenclature table is included (Table T3).

\section{Methods}

To create a depth profile of particle sizes at Site C0009, we analyzed the particle size distribution of a total of 46 samples. The samples were primarily from $10 \mathrm{~cm}^{3}$ plug samples taken shipboard. The wet-sieve and hydrometer techniques were used, which generated particle size distributions for each sample. The procedure used at the University of Texas at Austin (USA) for this study is described below. It is slightly modified from that used in Sawyer et al. (2008). This procedure is internationally recognized as a standard in the American Standard for Testing and Materials (ASTM International, 2007) and in the British Standard Institution (British Standard Institution, 1990). These size distributions were binned into sand, silt, and clay percentages for each sample. We used a clay-silt-sand ternary diagram using the Shepard classification (Shepard, 1954) to classify the samples.

\section{Principles of hydrometer analysis}

Germaine and Germaine (2009) discuss hydrometer analysis and the physical principles of sedimentation. The terminal velocity at which spherical particles settle through a column of fluid can be described by Stokes' law (Craig, 1992). Stoke's law assumes that particles are (1) rigid, spherical, and smooth; (2) of similar density; (3) separated from each other; (4) do not interact during sedimentation; and (5) are large enough that Brownian motion does not control settlement. This approach is applicable for particle sizes ranging from 0.0002 to $0.1 \mathrm{~mm}$ (Germaine and Germaine, 2009). The general approach is to mix the sediment into a suspension and then allow sedimentation while measuring the density of the suspended sediment at a specific depth.

The diameter of the largest particle in suspension $(D)$ is

$$
D=\sqrt{\frac{18 \mu}{\rho_{\mathrm{w}} g\left(G_{\mathrm{s}}-1\right)} \times \frac{L}{t}},
$$

where

$$
\begin{aligned}
& D=\text { diameter of the particle }(\mathrm{cm}), \\
& \mu=\text { viscosity of water }(\mathrm{g} /[\mathrm{cm} \cdot \mathrm{s}]), \\
& G_{\mathrm{s}}=\text { specific gravity of sediment (dimensionless), } \\
& \rho_{\mathrm{w}}=\text { water density }\left(\mathrm{g} / \mathrm{cm}^{3}\right) \\
& \mathrm{g}=\text { force of gravity }\left(\mathrm{cm} / \mathrm{s}^{2}\right) \\
& L=\text { distance the particle falls }(\mathrm{cm}), \text { and } \\
& t=\text { time for fall }(\mathrm{s}) .
\end{aligned}
$$

The percent finer material $(N)$ at reading $\mathrm{m}$ is

$$
N_{\mathrm{m}}=\frac{G_{\mathrm{s}}}{G_{\mathrm{s}}-1}\left(\frac{V}{M_{\mathrm{D}}}\right) \rho_{\mathrm{c}}\left(R_{\mathrm{m}}-R_{\mathrm{w}, \mathrm{m}} \times 100\right),
$$

where

$$
\begin{aligned}
N_{\mathrm{m}}= & \text { percent finer material at reading m (\%), } \\
G_{\mathrm{s}}= & \text { the specific gravity of sediment (dimension- } \\
& \text { less), } \\
V= & \text { volume of suspension }\left(\mathrm{mm}^{3}\right), \\
M_{\mathrm{D}}= & \text { dry solid mass of hydrometer specimen }(\mathrm{g}), \\
R_{\mathrm{m}}= & \text { hydrometer reading in suspension at time } \\
& (t) \text { and temperature, T (dimensionless), } \\
R_{\mathrm{w}, \mathrm{m}}= & \text { hydrometer reading in water with disper- } \\
& \text { sant at the same temperature as for } R_{\mathrm{m}}(\mathrm{di}- \\
& \text { mensionless), and } \\
\mathrm{m}= & \text { reading number. }
\end{aligned}
$$

\section{Samples}

We analyzed 46 samples distributed across the interval between 1529 and 1591 mbsf. We analyzed samples with a wet mass between 25 and $45 \mathrm{~g}$ because it was determined that a mass $<25$ g produced inaccurate results.

\section{Sample preparation}

Samples were first manually disaggregated using a mortar and pestle. After recording the wet mass, the wet sample was mixed with $5 \mathrm{~g}$ of dispersing agent (sodium hexametaphosphate) and $\sim 200 \mathrm{~mL}$ of deionized water and allowed to sit for $24-48 \mathrm{~h}$. The mixture was further disaggregated for $1 \mathrm{~min}$ using a Hamilton-Beach malt mixer (ASTM International, 2007).

Once the sample was mixed, the slurry was washed through a $63 \mu \mathrm{m}$ sieve with deionized water and a spatula. Material that was unable to pass through the sieve was dried at $110^{\circ} \mathrm{C}$. The sample was then cooled and weighed to determine the percentage of sand for each sample.

The material that passed through the sieve was placed in a $1000 \mathrm{~mL}$ plastic cylinder and deionized 
water was added to create a total volume of $1000 \mathrm{~mL}$. Five to six cylinders were usually tested at one time.

\section{Hydrometer analysis}

The prepared suspension was mixed thoroughly with a plunging rod for $1 \mathrm{~min}$. The removal of the plunging rod marked the beginning of the sedimentation process. Two sets of hydrometer readings were obtained for the first $2 \mathrm{~min}$ (each at 15, 30, 60, 90, and 120 s) of sedimentation with the hydrometer remaining in the suspension. The hydrometer was then removed, rinsed and wiped dry. Readings were then taken at larger increments of time $(4,8,16,32$, 64 , etc., minutes), with the hydrometer being inserted and removed right before and after the time mark, until the largest particle in solution (Equation 1) was $>0.002 \mathrm{~m}$ (the clay/silt boundary assumed). The temperature in the laboratory was monitored with a thermometer in a cylinder filled with deionized water and salt. At the end of the experiment, the slurry was poured into an evaporating dish and dried in an oven at $110^{\circ} \mathrm{C}$ to obtain the final dry mass of sediment and dispersing agent.

The hydrometer has to be calibrated prior to testing to obtain information for three factors: the meniscus rise, the effective reading depth for any particular reading, and the changes in fluid density with temperature and dispersing agent (Germaine and Germaine, 2009). For the effective reading depth $(L)$, two relationships are required: one for situations when the hydrometer remains in the suspension continuously and one for situations when the hydrometer is inserted for the reading (Germaine and Germaine, 2009). For times $\leq 2 \mathrm{~min}$, the effective reading depth $(L)$ is described by

$$
L=H_{\mathrm{r}, 1}-\frac{\left(H_{\mathrm{r}, 1}-H_{\mathrm{r}, 2}\right)}{\left(R_{\mathrm{h}, 2}-R_{\mathrm{h}, 1}\right)} \times\left(R_{\mathrm{h}}+c_{\mathrm{mr}}-R_{\mathrm{h}, 1}\right),
$$

where

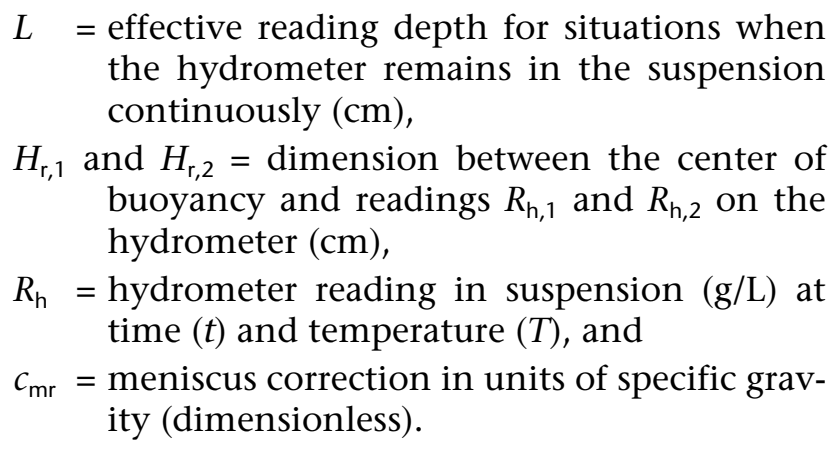

For times $<2 \mathrm{~min}$, an immersion correction $\left(V_{\mathrm{h}} / 2 A\right)$ was applied to the readings to account for the fact that the insertion of the hydrometer into the suspension stretches the column of fluid:

$$
L=H_{\mathrm{r}, 1}-\frac{\left(H_{\mathrm{r}, 1}-H_{\mathrm{r}, 2}\right)}{\left(R_{\mathrm{h}, 2}-R_{\mathrm{h}, 1}\right)} \times\left(R_{\mathrm{h}}+c_{\mathrm{mr}}-R_{\mathrm{h}, 1}\right)-\frac{V_{\mathrm{h}}}{2 A},
$$

where

$L=$ effective reading depth for situations when the hydrometer is inserted before individual readings $(\mathrm{cm})$

$V_{\mathrm{h}}=$ volume of hydrometer bulb up to the base of the stem $\left(\mathrm{cm}^{3}\right)$, and

$A=$ cross-section area of cylinder $\left(\mathrm{cm}^{2}\right)$.

Grain densities were not measured on the samples that we performed grain size analysis on. Instead, density was estimated from shipboard moisture and density (MAD) measurements. These measurements ranged between 2.42 and $3.01 \mathrm{~g} / \mathrm{cm}^{3}$ (Table T2). We used the average of two or three MAD grain density measurements take near the depths of the sample that we performed grain size analysis on.

\section{Results}

Particle size distribution curves were created for all 46 samples. Table $\mathrm{T} 1$ gives the sand, silt, and clay percentages calculated using the hydrometer analysis. Figures F2 and F3 show an example data sheet and plot for our hydrometer analysis (see GRAINSIZ in "Supplementary material" for similar graphs for each sample).

Figure F4 shows a particle distribution graph showing depth versus grain density and weight percent clay. Because we did not measure the density of the actual grain size samples, we determined an error resulting from using MAD density values from depths that are close to the depth of the grain size samples. To test the error in our grain density, we present the data using three constant grain density values. We calculated all grain size distributions to have a grain density of $2.7 \mathrm{~g} / \mathrm{cm}^{3}$ as an average specific gravity. We then altered all 46 samples to have a specific gravity of 2.6 and 2.8. The fraction of clay present varied only $\pm 0.8 \%$ compared to the grain size distribution with a specific gravity of 2.7. This demonstrates that variation in grain density over a reasonable range has a small effect on the interpreted grain size distribution.

Using the ternary diagram in Figure $\mathbf{F 5}$, we plot the sand, silt, and clay percentages for all 46 samples. Nearly all samples are within the clayey-silt field with a few scattered sandy-silts, silty-sands, and sands. The samples are more clay rich in the upper- 
most section, as seen in the particle distribution graph (Fig. F6).

The downcore profile for sand, silt, and clay against gamma ray, spontaneous potential, resistivity, lithology, and core information is shown in Figure F6.

\section{Reproducibility}

We used excess material from the samples to run a repeat experiment of Sample 319-C0009A-5R-1W, $126.0-129.5 \mathrm{~cm}$. We conducted one test where multiple hydrometer runs were taken on a single sample. The initial masses of the samples were varied (37.52 and 31.61 g) (Fig. F7).

The particle size distribution curves generally match each other with only minor variation in two parts (Fig. F7). This deviation can be explained by recognizing the material was not homogenized. They were taken from the same core, interval, and depth, but were separated into two packages. We assume therefore that our methods are reproducible.

\section{Acknowledgments}

All samples used in this study were collected during Integrated Ocean Drilling Program (IODP) Expedition 319. Funding for this research was provided by the U.S. Science Support Program, administered by the Consortium for Ocean Leadership. We thank the Expedition 319 crew and science party.

\section{References}

ASTM International, 2007. Standard test method for particle-size analysis of soils (Standard D422-63[2007]). In Annual Book of ASTM Standards (Vol. 04.08): Soil and Rock (I): West Conshohocken, PA (Am. So. Testing Mater.). doi:10.1520/D0422-63R07

British Standards Institution, 1990. Methods of Test for Soils for Civil Engineering Purposes (Standard BS-1377[1990]): London (British Standards Inst.).
Craig, R.F., 1992. Soil Mechanics (5th ed.): London (Chapman and Hall).

Expedition 319 Scientists, 2010. Site C0009. In Saffer, D., McNeill, L., Byrne, T., Araki, E., Toczko, S., Eguchi, N., Takahashi, K., and the Expedition 319 Scientists, Proc. IODP, 319: Tokyo (Integrated Ocean Drilling Program Management International, Inc.). doi:10.2204/ iodp.proc.319.103.2010

Germaine, J.T., and Germaine, A.V., 2009. Geotechnical Laboratory Measurements for Engineers: Hoboken, NJ (Wiley). doi:10.1002/9780470548790

Heki, K., 2007. Secular, transient, and seasonal crustal movements in Japan from a dense GPS array: implication for plate dynamics in convergent boundaries. In Dixon, T.H., and Moore, J.C. (Eds.), The Seismogenic Zone of Subduction Thrust Faults: New York (Columbia Univ. Press), 512-539.

Saffer, D., McNeill, L., Araki, E., Byrne, T., Eguchi, N., Toczko, S., Takahashi, K., and the Expedition 319 Scientists, 2009. NanTroSEIZE Stage 2: NanTroSEIZE riser/ riserless observatory. IODP Prel. Rept., 319. doi:10.2204/ iodp.pr.319.2009

Sawyer, D.E., Jacoby, R., Flemings, P., and Germaine, J.T., 2008. Data report: particle size analysis of sediments in the Ursa Basin, IODP Expedition 308 Sites U1324 and U1322, northern Gulf of Mexico. In Flemings, P.B., Behrmann, J.H., John, C.M., and the Expedition 308 Scientists, Proc. IODP, 308: College Station, TX (Integrated Ocean Drilling Program Management International, Inc.). doi:10.2204/iodp.proc.308.205.2008

Seno, T., Stein, S., and Gripp, A.E., 1993. A model for the motion of the Philippine Sea plate consistent with NUVEL-1 and geological data. J. Geophys. Res.: Solid Earth, 98(B10):17941-17948. doi:10.1029/93JB00782

Shepard, F.P., 1954. Nomenclature based on sand-silt-clay ratios. J. Sediment. Res., 24(3):151-158. doi:10.1306/ D4269774-2B26-11D7-8648000102C1865D

Initial receipt: 19 April 2013

Acceptance: 21 January 2015

Publication: 1 May 2015

MS 319-203 
Figure F1. Map of study area showing drill sites, Sites C0009 and C0010 (green diamonds) (modified from Saffer et al., 2009). Red circles $=$ NanTroSEIZE Stage 1 sites, black box $=$ location of 3-D reflection data acquisition in 2006, yellow arrows = vectors estimated far-field between Philippine Sea plate and Japan (Heki, 2007; Seno, 1993), stars = large earthquakes in the past.

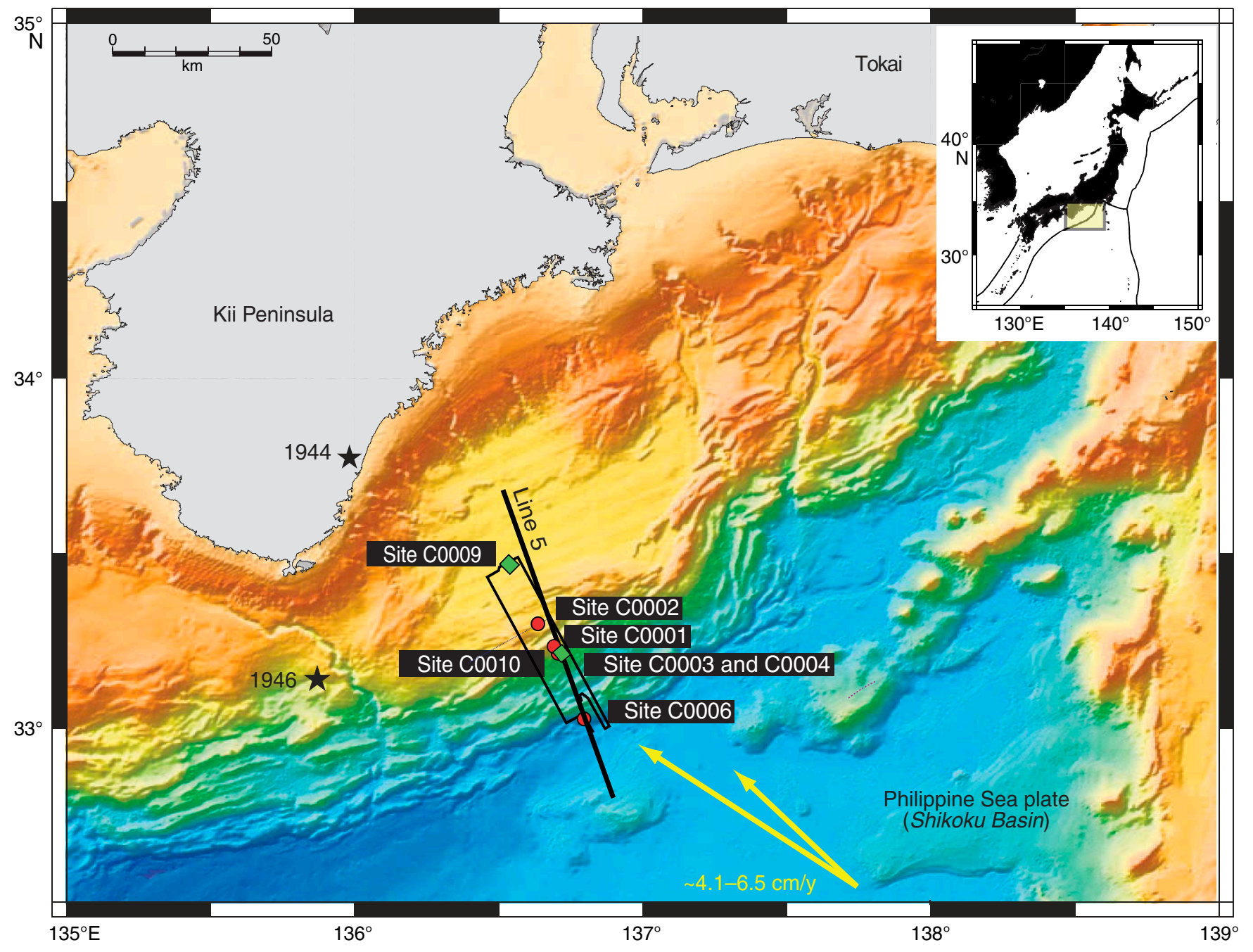


Figure F2. Example data sheet for hydrometer analyses, Site C0009.

Hydrometer Analysis

\begin{tabular}{|c|c|c|c|c|c|c|c|c|}
\hline & & & & & & & Test No & GS054 \\
\hline Project : IOL & Expedition & 319 & & & & & Tested by & CAA \\
\hline & & & & & & & Test Date & $4 / 20 / 2010$ \\
\hline Boring : $\mathrm{CO}$ & & & Hydrometer: & $151 \mathrm{H}$ Fis & her Brand & Volumetric & & \\
\hline Sample: $3 \mathrm{R}$ & $4-62 \mathrm{~cm}$ & & Number $=$ & 98 & & Volume $=$ & 1000 & $\left.m^{3}\right)$ \\
\hline Location: $\mathrm{Na}$ & & & Volume $=$ & 69.59 & $\left(\mathrm{~cm}^{3}\right)$ & Area $=$ & 28.77 & $\left.m^{2}\right)$ \\
\hline Spec. Grav & 2.66 & & $\mathrm{Hr} @ 1035=$ & 8.2 & $(\mathrm{~cm})$ & Mass Meas & urement & \\
\hline Dry Soil Mas & 36.18 & (gm) & $\mathrm{Hr} @ 1000=$ & 17.5 & $(\mathrm{~cm})$ & Tare, s & il, disp. = & $353.35(\mathrm{gm})$ \\
\hline Mass Disp & 5.00 & (gm) & Meniscus $=$ & 0.4 & $(\mathrm{gm} / \mathrm{l})$ & & Tare $=$ & $316.25 \quad(\mathrm{gm})$ \\
\hline No & Disp. not i & ncluded in dry & y mass. & & Note: Read & hydrometer & o 0.2 gm/l & \\
\hline & Measu & drements & & & Const & tants & & esults \\
\hline $\begin{array}{c}\text { Date } \\
\text { (mm/dd/yyyy) }\end{array}$ & $\begin{array}{c}\text { Elasped } \\
\text { Time } \\
\text { (min) }\end{array}$ & $\begin{array}{c}\text { Suspension } \\
\text { Reading } \\
\left(\mathrm{SG}^{*} 1000\right)\end{array}$ & $\begin{array}{c}\text { Water / Disp. } \\
\text { Reading } \\
\left(\mathrm{SG}^{*} 1000\right)\end{array}$ & $\begin{array}{l}\text { Temp. } \\
\text { (C) }\end{array}$ & $\begin{array}{l}\text { Viscosity } \\
\left(\mathrm{gm}^{-}\right. \\
\left.\mathrm{sec} / \mathrm{cm}^{2}\right)\end{array}$ & $\begin{array}{c}\begin{array}{c}\text { Reading } \\
\text { Depth } \\
(\mathrm{cm})\end{array} \\
\end{array}$ & $\begin{array}{l}\text { Percent } \\
\text { Finer (\%) }\end{array}$ & $\begin{array}{l}\text { Diameter } \\
(\mathrm{mm})\end{array}$ \\
\hline $4 / 20 / 2010$ & 0.33 & 1023.1 & 1003.9 & 23.0 & $9.56 \mathrm{E}-06$ & 11.3 & 85.2 & 0.07678 \\
\hline $4 / 20 / 2010$ & 0.5 & 1022.7 & 1003.9 & 23.0 & $9.56 \mathrm{E}-06$ & 11.4 & 83.4 & 0.06267 \\
\hline $4 / 20 / 2010$ & 1 & 1021.9 & 1003.9 & 23.0 & 9.56E-06 & 11.6 & 79.9 & 0.04473 \\
\hline $4 / 20 / 2010$ & 1.5 & 1021.1 & 1003.9 & 23.0 & 9.56E-06 & 11.8 & 76.3 & 0.03685 \\
\hline $4 / 20 / 2010$ & 2 & 1020.5 & 1003.9 & 23.0 & 9.56E-06 & 11.9 & 73.7 & 0.03213 \\
\hline $4 / 20 / 2010$ & 4 & 1019.2 & 1003.9 & 23.0 & $9.56 \mathrm{E}-06$ & 11.1 & 67.9 & 0.02188 \\
\hline $4 / 20 / 2010$ & 8.0 & 1018.1 & 1003.9 & 23.0 & 9.56E-06 & 11.4 & 63.0 & 0.01568 \\
\hline $4 / 20 / 2010$ & 16 & 1016.2 & 1003.9 & 23.0 & 9.56E-06 & 11.9 & 54.6 & 0.01133 \\
\hline $4 / 20 / 2010$ & 32 & 1014.9 & 1003.9 & 23.0 & $9.56 \mathrm{E}-06$ & 12.2 & 48.9 & 0.00813 \\
\hline $4 / 20 / 2010$ & 65 & 1013.2 & 1003.9 & 23.0 & 9.56E-06 & 12.7 & 41.3 & 0.00581 \\
\hline $4 / 20 / 2010$ & 128 & 1012.0 & 1003.9 & 23.0 & 9.56E-06 & 13.0 & 36.0 & 0.00419 \\
\hline $4 / 20 / 2010$ & 210 & 1011.0 & 1003.9 & 23.0 & 9.56E-06 & 13.3 & 31.6 & 0.00330 \\
\hline $4 / 20 / 2010$ & 460 & 1010.0 & 1003.9 & 23.0 & 9.56E-06 & 13.5 & 27.1 & 0.00225 \\
\hline $4 / 20 / 2010$ & 1413 & 1009.6 & 1003.9 & 23.0 & 9.56E-06 & 13.6 & 25.4 & 0.00129 \\
\hline $4 / 21 / 2010$ & 1891 & 1009.2 & 1003.9 & 23.0 & 9.56E-06 & 13.7 & 23.6 & 0.00112 \\
\hline $4 / 21 / 2010$ & 2843 & 1007.8 & 1003.9 & 23.0 & 9.56E-06 & 14.1 & 17.4 & 0.00093 \\
\hline $4 / 26 / 2010$ & 10042 & 1006.9 & 1003.9 & 23.0 & 9.56E-06 & 14.4 & 13.4 & 0.00050 \\
\hline Sieve Data (wet sie & at $63 \mu \mathrm{m})$ & & & & Interpolatec & silt/clay bc & undary (at & $\mu \mathrm{m})$ \\
\hline Mass retai & on sieve: & 4.080 & $(g m)$ & & Percent pa & ssing $2 \mu \mathrm{m}$ : & 26.7 & $(\%)$ \\
\hline Sand-percen & dry mass: & 11.28 & $(\%)$ & & & Diameter: & 0.002 & $(\mathrm{~mm})$ \\
\hline Percent pa & ng $63 \mu \mathrm{m}$ : & 88.72 & $(\%)$ & & & & & \\
\hline & Diameter: & 0.0630 & $(\mathrm{~mm})$ & & & & & \\
\hline Remarks: & s greate & than 2 minut & tes, an immers & ion corre & ction is appli & ed to the rea & dings. & \\
\hline
\end{tabular}


Figure F3. Sample particle size distribution plotted on a semilog scale, Site C0009. Black circles $=$ hydrometer readings, diamond = sand fraction from wet sieving through $63 \mu \mathrm{m}$ sieve. The sand/silt boundary is defined at $63 \mu \mathrm{m}$ and the silt/clay boundary is defined at $2 \mu \mathrm{m}$. See GRAINSIZ in "Supplementary material" for test results.

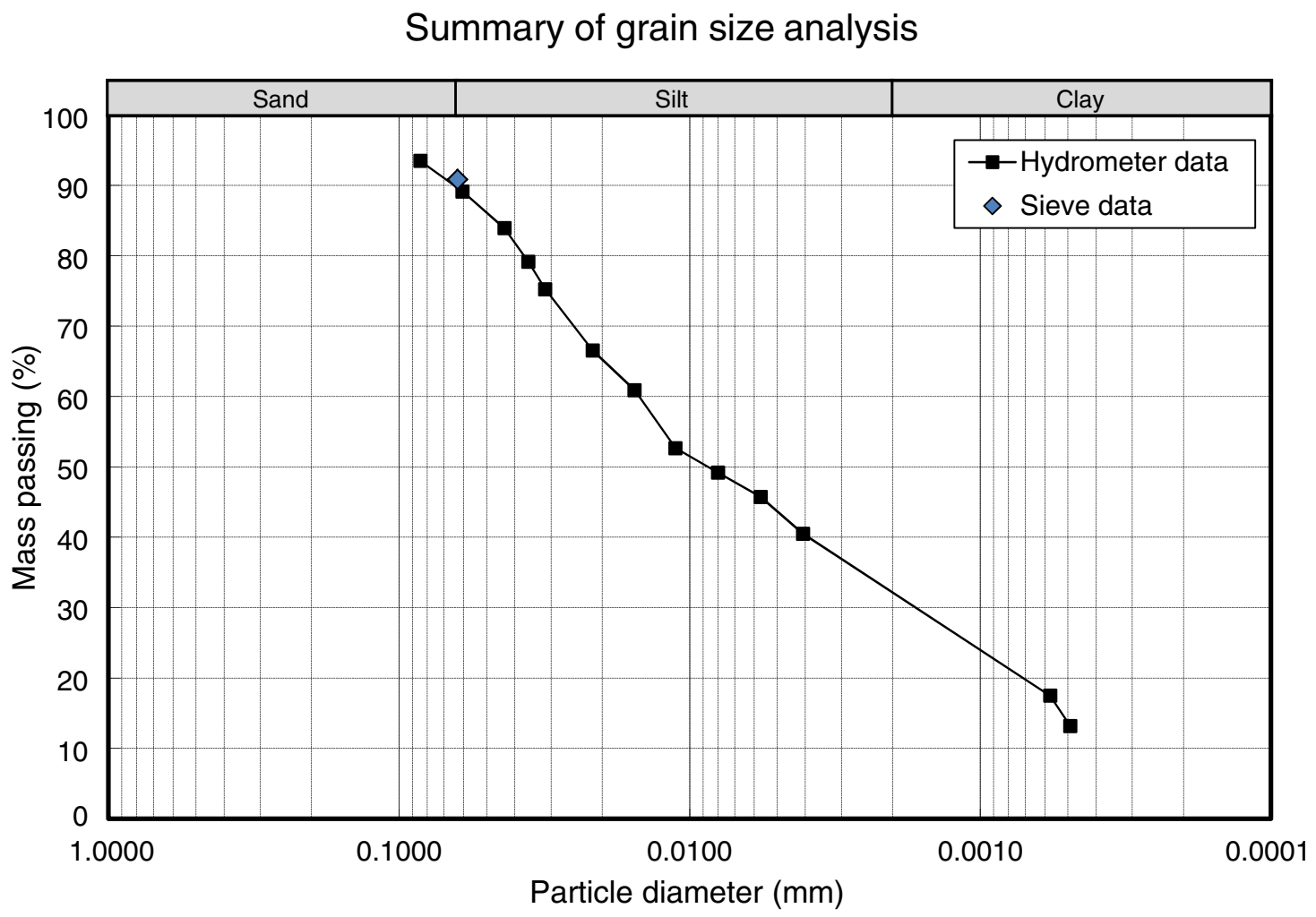


Figure F4. Grain density and clay fraction vs. depth for all measured samples, Site C0009. A. Grain density measured by shipboard scientists (Table T2). B. Grain density used for analyses, determined by averaging two or three MAD grain density measurements. C. Clay fractions determined from hydrometer analyses using grain density shown in B. Gray = clay fraction, white = silt and sand fraction. Positive and negative error bars in clay fraction are determined from using grain density values of 2.6 and $2.8 \mathrm{~g} / \mathrm{cm}^{3}$ relative to $2.7 \mathrm{~g} / \mathrm{cm}^{3}$ in the clay fraction calculation, respectively.
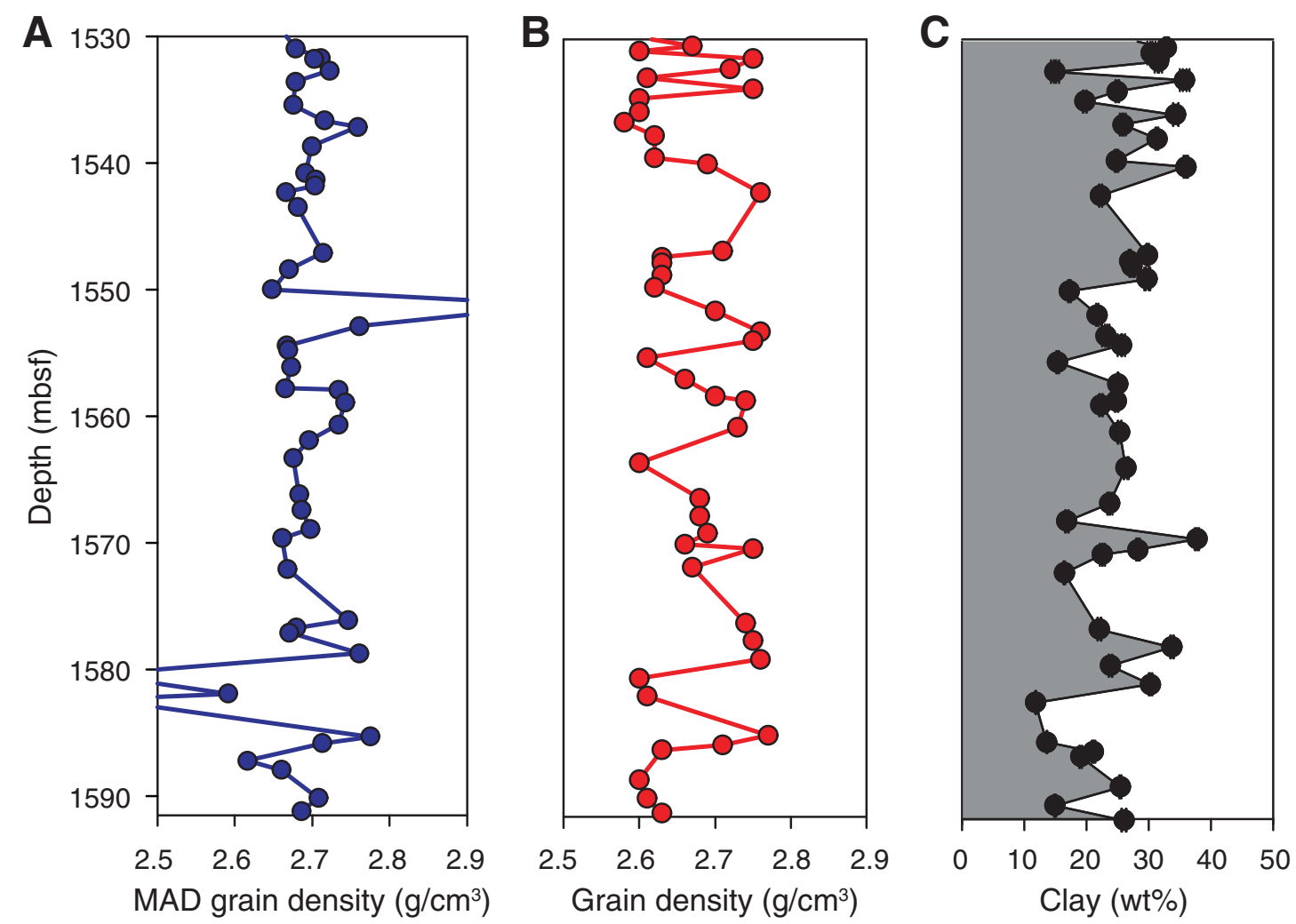
Figure F5. Ternary diagram of all 46 samples from Hole C0009A using Shepard's (1954) sediment classification scheme.

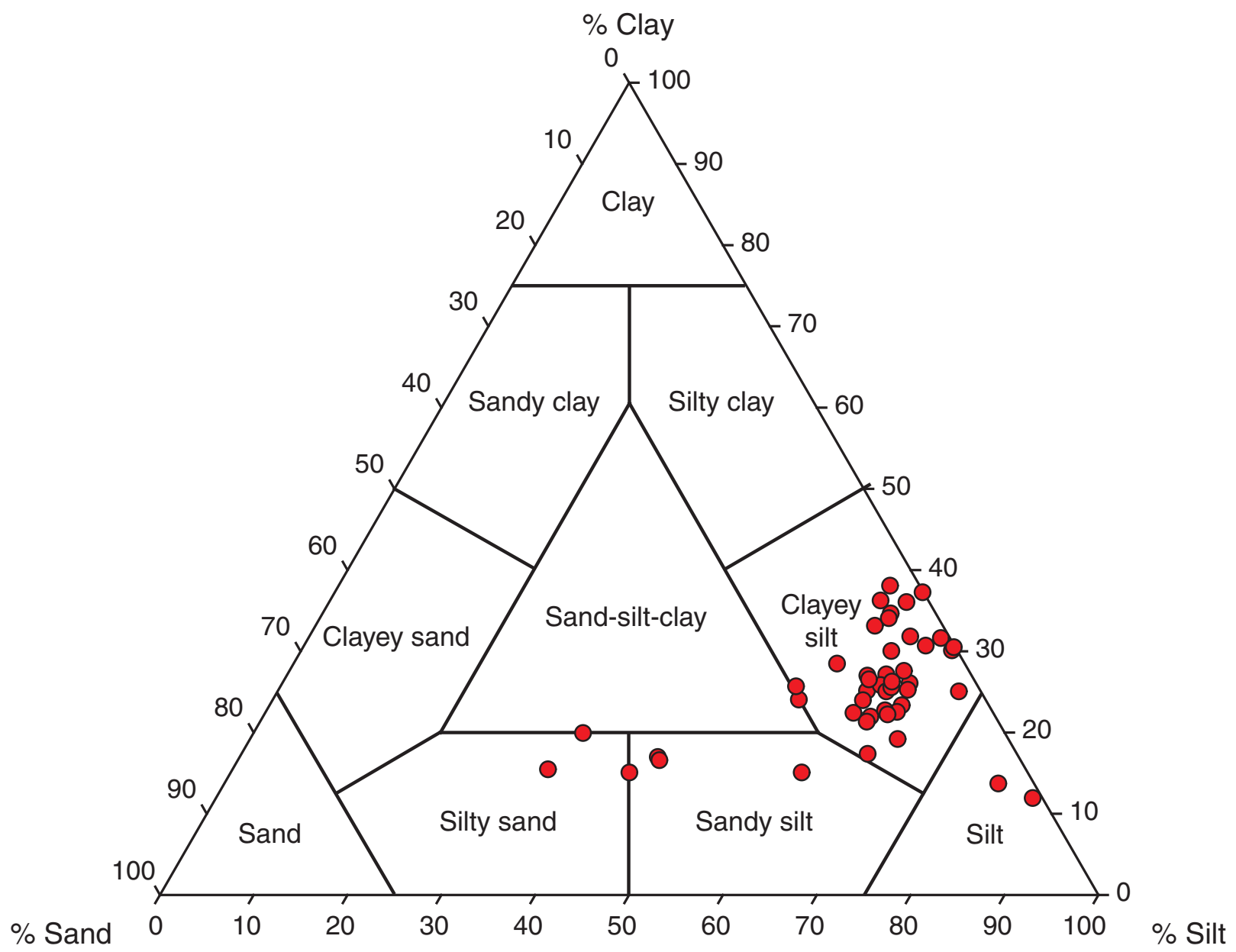


Figure F6. Summary plot of downhole logs and particle distribution, Site C0009. Spontaneous potential (SP), gamma ray (GR), and resistivity are wireline data. Lithologic fractions were experimentally determined by our grain size analyses of all 46 samples. Core recovered: black = actual interval of sediment retrieved by the expedition, white = gaps where no core was recovered. Each core was assigned a core number. Lithologic units were defined by shipboard sedimentologists.

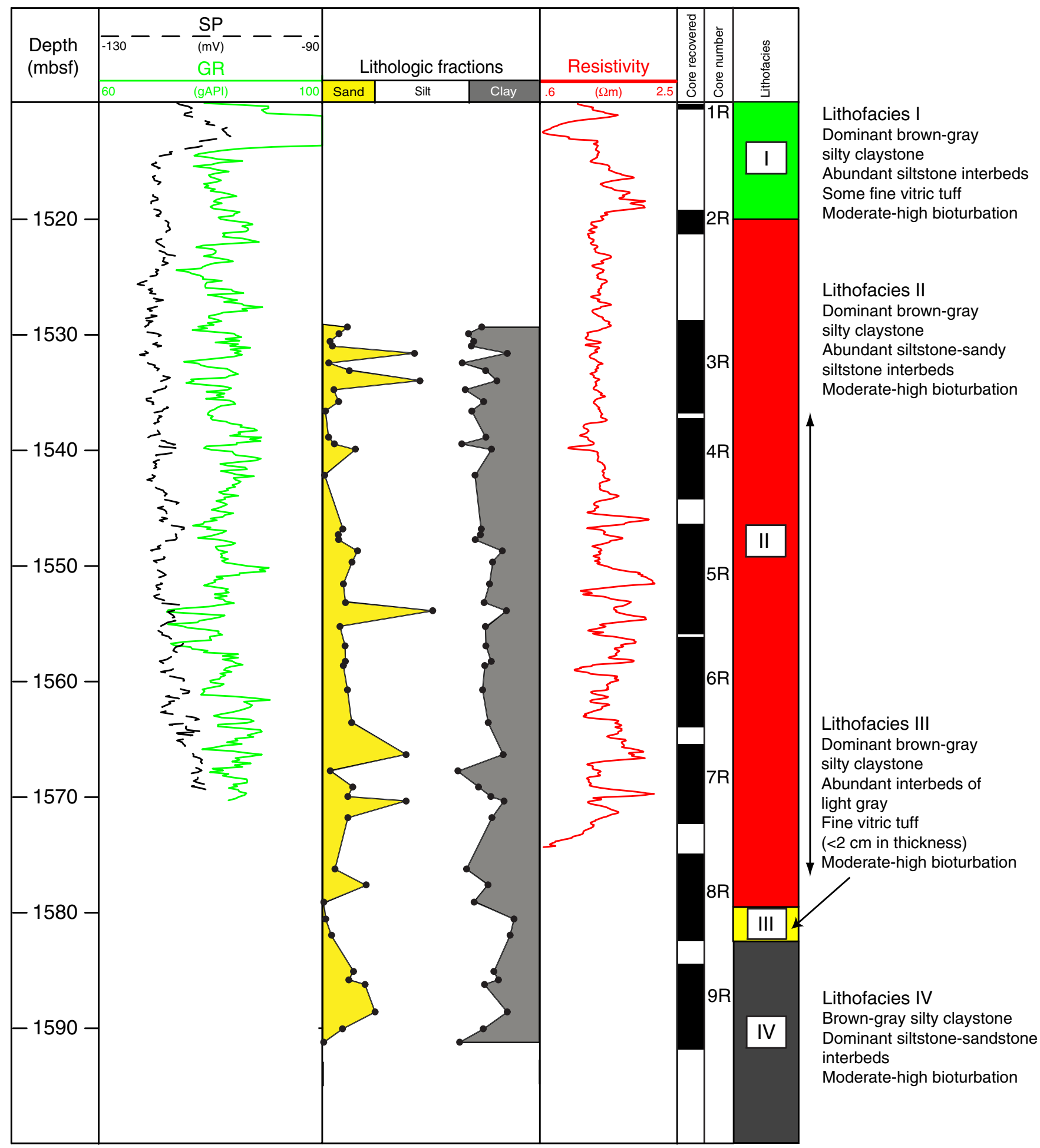


Figure F7. Graph of two hydrometer tests (GS071 and GS115) on the same sample from 1547.66 mbsf to illustrate reproducibility. The initial mass of the samples also varied. Sample GS115 had a mass of $31.61 \mathrm{~g}$ and Sample GS071 had a mass of $37.52 \mathrm{~g}$.

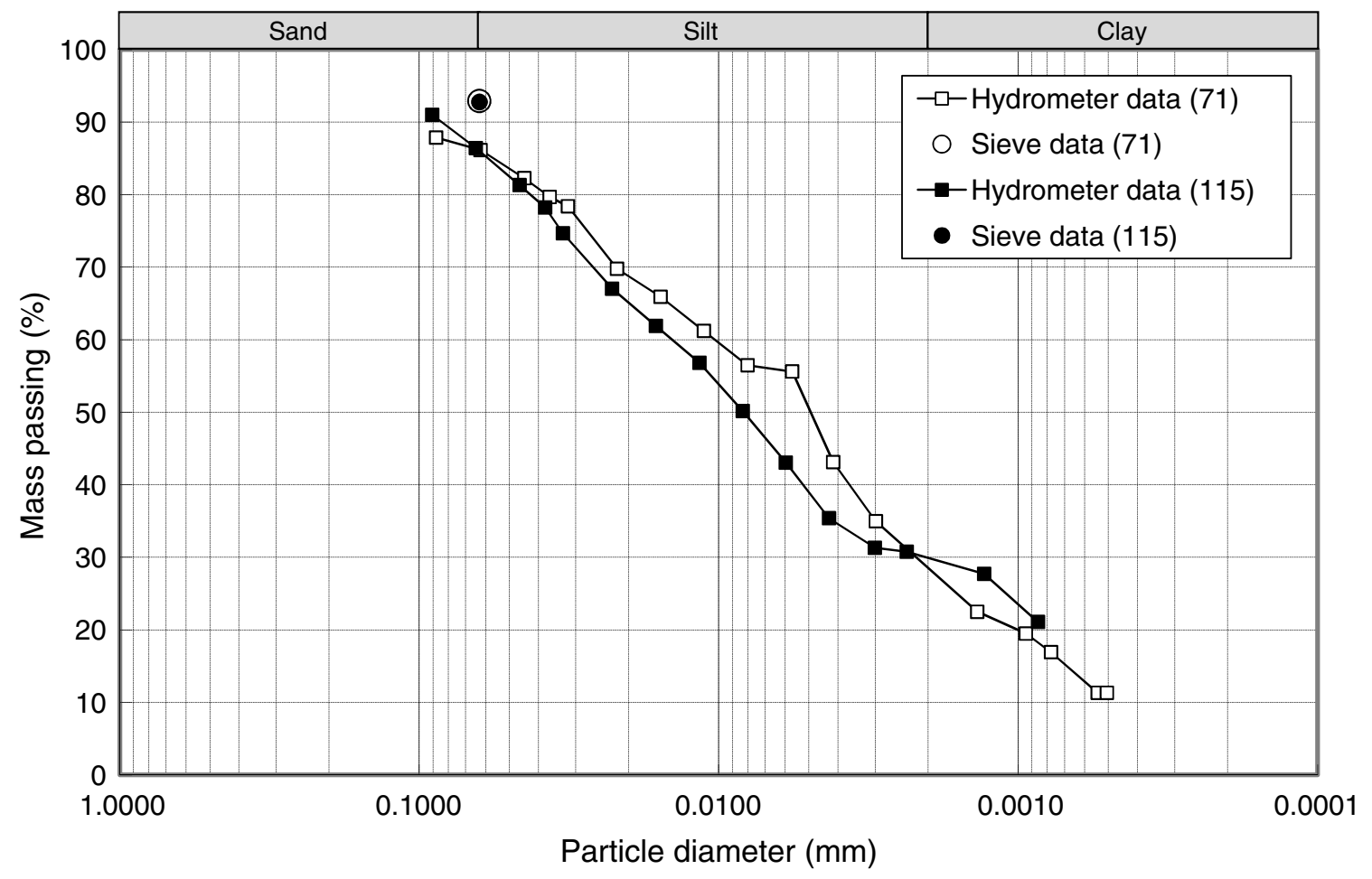


Table T1. Hole C0009A core summary and particle size distribution data.

\begin{tabular}{|c|c|c|c|c|c|}
\hline \multicolumn{2}{|c|}{ Core information } & \multicolumn{4}{|c|}{ Grain size information } \\
\hline $\begin{array}{l}\text { Core, section, } \\
\text { interval }(\mathrm{cm})\end{array}$ & Depth (mbsf) & $\begin{array}{c}\text { Test } \\
\text { number }\end{array}$ & $\begin{array}{l}\text { Sand } \\
\text { (wt\%) }\end{array}$ & $\begin{array}{l}\text { Silt } \\
\text { (wt\%) }\end{array}$ & $\begin{array}{l}\text { Clay } \\
\text { (wt\%) }\end{array}$ \\
\hline \multicolumn{6}{|l|}{ 319-C0009A- } \\
\hline $3 R-1,58.0-62.0$ & $1529.28-1529.32$ & GS054 & 11.3 & 62.0 & 26.7 \\
\hline $3 R-1,114.5-116.0$ & $1529.845-1529.86$ & GS111 & 7.4 & 59.8 & 32.8 \\
\hline $3 R-2,40.5-44.5$ & $1530.515-1530.555$ & GS069 & 3.3 & 66.4 & 30.4 \\
\hline $3 \mathrm{R}-2,81.0-85.0$ & $1530.92-1530.96$ & GS112 & 4.4 & 64.2 & 31.5 \\
\hline $3 R-3,17.5-21.5$ & $1531.545-1531.585$ & GS106 & 42.3 & 42.8 & 14.9 \\
\hline $3 R-4,32.0-36.0$ & $1532.365-1532.405$ & GS076 & 2.7 & 61.6 & 35.7 \\
\hline 3R-4, 99.0-103.0 & 1533.035-1533.075 & GS120 & 12.2 & 62.9 & 24.9 \\
\hline 3R-5, 44.0-48.0 & $1533.92-1533.96$ & GS107 & 44.8 & 35.5 & 19.7 \\
\hline $3 R-5,122.0-127.0$ & $1534.7-1534.75$ & GS114 & 5.0 & 60.7 & 34.3 \\
\hline $3 R-6,84.0-88.5$ & $1535.735-1536.115$ & GS081 & 7.2 & 67.0 & 25.8 \\
\hline $3 R-7,24.0-28.0$ & $1536.545-1536.585$ & GS087 & 1.2 & 67.5 & 31.3 \\
\hline $4 \mathrm{R}-2,51.0-56.0$ & $1538.81-1538.86$ & GS070 & 2.6 & 72.6 & 24.8 \\
\hline 4R-2, 107.0-111.0 & 1539.37-1539.41 & GS116 & 5.3 & 58.8 & 35.9 \\
\hline $4 R-4,11.0-15.0$ & $1539.86-1539.9$ & GS077 & 15.0 & 62.8 & 22.2 \\
\hline 4R-7, 25.0-29.0 & $1542.11-1542.15$ & GS088 & 0.8 & 69.4 & 29.8 \\
\hline $5 R-1,36.0-42.0$ & $1546.76-1546.82$ & GS056 & 9.2 & 64.0 & 26.9 \\
\hline $5 R-1,85.5-90.5$ & $1547.255-1547.305$ & GS071 & 7.1 & 65.6 & 27.3 \\
\hline $5 R-1,126.0-129.5$ & 1547.66-1547.695 & GS115 & 7.2 & 63.1 & 29.7 \\
\hline $5 R-2,85.5-90.5$ & $1548.655-1548.705$ & GS118 & 16.0 & 66.8 & 17.2 \\
\hline $5 R-3,48.0-52.5$ & $1549.62-1549.665$ & GS074 & 13.4 & 64.9 & 21.7 \\
\hline $5 R-5,53.5-58.0$ & $1551.495-1551.54$ & GS082 & 9.4 & 67.5 & 23.1 \\
\hline $5 R-6,127.0-131.0$ & $1553.12-1553.16$ & GS086 & 10.4 & 64.0 & 25.6 \\
\hline $5 R-7,61.0-65.0$ & $1553.85-1553.89$ & GS105 & 50.7 & 34.0 & 15.3 \\
\hline $5 R-8,55.0-59.0$ & $1555.2-1555.24$ & GS122 & 7.9 & 67.2 & 25.0 \\
\hline $6 \mathrm{R}-1,100.0-104.0$ & 1556.9-1556.94 & GS057 & 10.2 & 65.0 & 24.8 \\
\hline 6R-3, 39.0-41.5 & $1558.235-1558.26$ & GS119 & 10.3 & 67.4 & 22.3 \\
\hline $6 \mathrm{R}-4,28.0-32.0$ & $1558.575-1558.615$ & GS078 & 9.4 & 65.3 & 25.3 \\
\hline 6R-5, 98.0-102.0 & $1560.69-1560.73$ & GS083 & 11.3 & 62.4 & 26.3 \\
\hline 6R-7, 97.0-101.0 & $1563.51-1563.55$ & GS110 & 13.3 & 63.1 & 23.7 \\
\hline 7R-1, 90.0-94.0 & $1566.3-1566.66$ & GS058 & 38.4 & 44.8 & 16.8 \\
\hline $7 R-2,90.0-94.0$ & $1567.705-1567.745$ & GS072 & 3.4 & 58.9 & 37.7 \\
\hline $7 R-3,88.0-92.0$ & 1569.095-1569.135 & GS075 & 13.7 & 58.1 & 28.2 \\
\hline $7 R-4,30.5-34.5$ & 1569.93-1569.97 & GS079 & 11.5 & 66.0 & 22.5 \\
\hline $7 R-4,69.0-73.0$ & $1570.315-1570.355$ & GS104 & 38.4 & 45.2 & 16.4 \\
\hline 7R-5, 72.0-76.0 & $1571.76-1571.8$ & GS084 & 11.5 & 66.5 & 22.0 \\
\hline $8 R-1,128.0-133.0$ & $1576.18-1576.23$ & GS059 & 5.5 & 60.8 & 33.7 \\
\hline $8 R-4,69.0-72.0$ & $1577.58-1577.61$ & GS108 & 20.0 & 56.3 & 23.8 \\
\hline $8 R-5,74.0-78.0$ & 1579.05-1579.09 & GS085 & 0.4 & 69.4 & 30.2 \\
\hline $8 R-6,80.0-84.0$ & $1580.53-1580.57$ & GS117 & 1.3 & 86.9 & 11.8 \\
\hline $8 R-7,78.0-82.0$ & 1581.95-1581.99 & GS123 & 4.0 & 82.4 & 13.6 \\
\hline $9 \mathrm{R}-1,67.0-71.0$ & $1585.07-1585.11$ & GS060 & 14.1 & 64.8 & 21.1 \\
\hline $9 \mathrm{R}-2,0.0-4.0$ & 1585.8-1585.84 & GS073 & 11.9 & 69.1 & 19.0 \\
\hline $9 \mathrm{R}-2,41.0-45.0$ & $1586.21-1586.25$ & GS109 & 19.4 & 55.2 & 25.4 \\
\hline $9 \mathrm{R}-4,77.0-81.0$ & $1588.58-1588.62$ & GS080 & 24.1 & 61.0 & 14.9 \\
\hline $9 \mathrm{R}-6,81.0-85.0$ & $1590.05-1590.09$ & GS121 & 9.0 & 65.0 & 26.0 \\
\hline $9 R-7,55.0-58.0$ & $1591.2-1591.23$ & GS113 & 0.3 & 62.8 & 36.9 \\
\hline
\end{tabular}


Table T2. Hole C0009A grain density measurements from moisture and density (MAD) measurements.

\begin{tabular}{|c|c|}
\hline $\begin{array}{l}\text { Top core depth } \\
\text { below seafloor } \\
\text { (m CSF-A) }\end{array}$ & $\begin{array}{l}\text { MAD Method } \\
\text { C grain density } \\
\left(\mathrm{g} / \mathrm{cm}^{3}\right)\end{array}$ \\
\hline 1509.8 & 2.4447 \\
\hline 1519.57 & 2.6737 \\
\hline 1520.18 & 2.6776 \\
\hline 1529.48 & 2.6615 \\
\hline 1530.96 & 2.6781 \\
\hline 1531.71 & 2.7111 \\
\hline 1531.77 & 2.7024 \\
\hline 1532.685 & 2.7224 \\
\hline 1533.58 & 2.6785 \\
\hline 1535.415 & 2.676 \\
\hline 1536.635 & 2.7154 \\
\hline 1537.155 & 2.759 \\
\hline 1538.65 & 2.6993 \\
\hline 1540.78 & 2.6913 \\
\hline 1541.33 & 2.7039 \\
\hline 1541.79 & 2.7035 \\
\hline 1542.28 & 2.666 \\
\hline 1543.5 & 2.6811 \\
\hline 1547.08 & 2.7137 \\
\hline 1548.39 & 2.67 \\
\hline 1549.99 & 2.6485 \\
\hline 1551.22 & 3.0145 \\
\hline 1552.87 & 2.7612 \\
\hline 1554.41 & 2.6671 \\
\hline 1554.78 & 2.6689 \\
\hline 1556.1 & 2.6726 \\
\hline 1557.79 & 2.6657 \\
\hline 1557.895 & 2.7344 \\
\hline 1558.91 & 2.7428 \\
\hline 1560.64 & 2.7342 \\
\hline 1561.925 & 2.6961 \\
\hline 1563.27 & 2.6755 \\
\hline 1566.16 & 2.6834 \\
\hline 1567.385 & 2.6866 \\
\hline 1568.875 & 2.6975 \\
\hline 1569.625 & 2.661 \\
\hline 1572.06 & 2.6678 \\
\hline 1576.075 & 2.7463 \\
\hline 1576.7 & 2.6794 \\
\hline 1577.08 & 2.6705 \\
\hline 1578.7 & 2.7608 \\
\hline 1580.35 & 2.4217 \\
\hline 1581.92 & 2.592 \\
\hline 1582.3 & 2.4206 \\
\hline 1585.28 & 2.7749 \\
\hline 1585.8 & 2.7128 \\
\hline 1587.2 & 2.6162 \\
\hline 1587.93 & 2.66 \\
\hline 1590.15 & 2.7081 \\
\hline 1591.16 & 2.6862 \\
\hline
\end{tabular}


Table T3. Nomenclature.

\begin{tabular}{|c|c|c|}
\hline Name & Definition & Unit \\
\hline D & Particle diameter & $\mathrm{cm}$ \\
\hline g & Gravitational force & $\mathrm{cm} / \mathrm{s}^{2}$ \\
\hline $\mathrm{C}_{\mathrm{s}}$ & Specific gravity of sediment & dimensionless \\
\hline$L$ & Distance the particle falls & $\mathrm{cm}$ \\
\hline $\mathrm{m}$ & Reading number & dimensionless \\
\hline$M_{D}$ & Dry solid mass of hydrometer specimen & $\mathrm{g}$ \\
\hline$N_{\mathrm{m}}$ & Percent-finer material at reading $\mathrm{m}$ & $\%$ \\
\hline$V$ & Volume of suspension & $\mathrm{mm}^{3}$ \\
\hline$R_{\mathrm{m}}$ & Hydrometer reading in suspension at time $(t)$, and temperature, $(T)$ & dimensionless \\
\hline$R_{\mathrm{w}, \mathrm{m}}$ & Hydrometer reading in water with dispersant at the same temperature as for $R_{\mathrm{m}}$ & dimensionless \\
\hline$t$ & Time for particle to fall & s \\
\hline$\mu$ & Viscosity of water & $\mathrm{g} /(\mathrm{cm} \cdot \mathrm{s})$ \\
\hline$\rho_{\mathrm{w}}$ & Water density & $\mathrm{g} / \mathrm{cm}^{3}$ \\
\hline
\end{tabular}

